\section{俩 Heighten Science \\ P U B L I C A T I O N S Corporation ISSN 2573-6191}

Editorial

\title{
Low Level Light Therapy (LLLT): Penetration and Photobiomodulation
}

\author{
Cecilia Young* and Cheuk Lam Mak \\ Physician, Pharmacist People Health Magazine, Hong Kong
}

Mester et al., stated the laser effects in a review of their studies of 15 various bio-

*Address for Correspondence: Dr. Cecilia Young, Physician, Pharmacist People Health Magazine, Hong Kong, Email: ceciliatyp@yahoo.com.hk

Submitted: 14 July 2017

Approved: 31 July 2017

Published: 31 July 2017

Copyright: @ 2017 Young C, et al. This is an open access article distributed under the Creative Commons Attribution License, which permits unrestricted use, distribution, and reproduction in any medium, provided the original work is properly cited. logical systems, they observed the stimulating effect of low energy (in terms of $\mathrm{J} / \mathrm{cm}^{2}$ ) laser and inhibiting effect of high energy laser and later reported the relationship of cumulative energy applied and the effects conforms to the Arndt-Schultz law. They concluded their experience with 875 healed cases and the results of their experiments had convinced them to recommend the use of lasers to stimulate wound healing [1].

Studies on the effects of Low Level Light Therapy reported pain relief $[2,3]$ and promotion of wound healing [2]. These effects are useful in the oro-maxillofacial region and other parts of the body.

Ohshiro introduced the concept of photobioactivation [4], he suggested that photobioactivation follows as a result of an exogenous photostimulus, and therefore follows the Arndt-Schultz law (Figure 1) [4].

For photobiostimulation to take place, the incident light needs to be delivered to target tissue in proper dosage, therefore the penetration of the light used is important. Optical properties of light depends on body tissues and wavelength. Studies have been done to investigate the optical window for various biological tissues and respective data are well-documented $[5,6]$.

Despite knowing correct ranges of wavelength, the skin is still a great barrier to LLLT treatment. The skin blocks out most of the incident energy by scattering and absorption, thus energy dosage for the deeper parts of the body remains at far left of the Ohshiro's Arndt-Schultz curve (Figure 1) [4], photobiostimulation of the treatment is actually insignificant, if better than no treatment at all at lower energy range.

Will raising the incident energy be the solution? Yes and No. Photobiomodulation is biphasic in nature: biostimulation occurs in low doses but bioinhibition arises in high doses. Absorption coefficient of human tissue is independent to light amplitude. Although increasing incident energy can deliver proper energy to deeper parts of the body, it may also result in bioinhibition to the superficial layer.

Finding a proper instrument for precise penetration measurement inside the body is also difficult. Jagdeo et al., measured the penetration of red $633 \mathrm{~nm}$ and infrared $830 \mathrm{~nm}$ through cadaver skull bones, sectioned cadaver skulls with intact soft tissue, in vivo human cheek, and in vivo human hand. Red and infrared behave differently in different areas [7]. Human hand and cheek were thin enough, but application to human brain and spine remains a great challenge due to its anatomical position.

Case reports and clinical studies e.g. for tooth movement [8] and palatal expansion $[9,10]$, tooth extraction [11,12], dental implants [13], Temporomandibular jaw 
disorders [14] and other oral surgeries [15], have recorded parameters like wavelength, power and energy dosage etc., without detailed explaining their choices. Most of the above mentioned studies did not mention which layer or depth is their target tissue. More investigation at different area and different depth should be performed in order to give more information for future treatment planning.

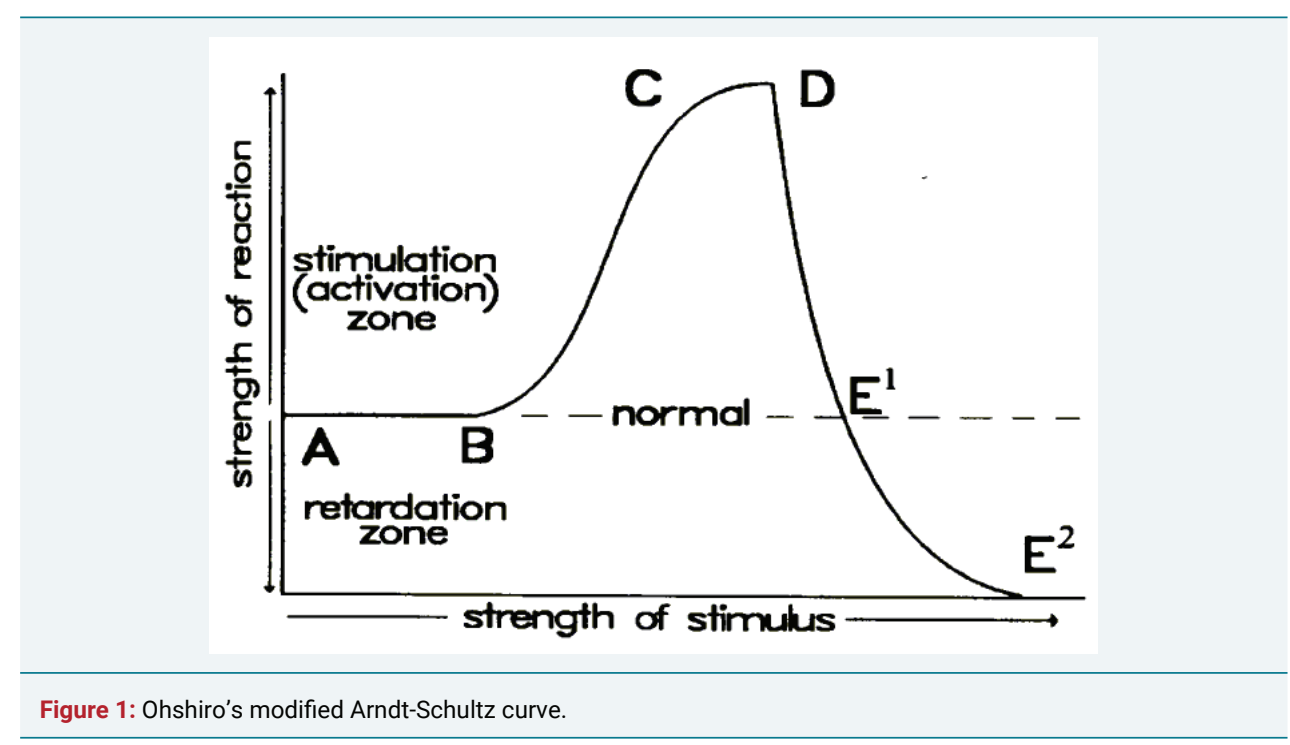

\section{REFERENCES}

1. Mester E, Mester AF, Mester A. The biomedical effects of laser application. Lasers in surgery and medicine. 1985; 5: 31-39. Ref.: https://goo.gl/cRAjBy

2. Suter VGA, Sjölund S, Bornstein MM. Effect of laser on pain relief and wound healing of recurrent aphthous stomatitis: a systematic review. Lasers Med Sci. 2017; 32: 953-963. Ref.: https://goo.gl/dK4NHF

3. Bjordal JM, Johnson MI, Iversen V, Aimbire F, Lopes-Martins RA. Low-level laser therapy in acute pain: a systematic review of possible mechanisms of action and clinical effects in randomized placebo-controlled trials. Photomed Laser Surg. 2006; 24: 158-168. Ref.: https://goo.gl/DRN456

4. Ohshiro T, Caldenhead RG. Development of low reactive-level laser therapy and its present status. Journal of clinical laser medicine \& surgery. 1991; 9: 267-275. Ref.: https://goo.gl/W9GSnG

5. Bashkatov A, Genina E, Kochubey V, Tuchin V. Optical properties of human skin, subcutaneous and mucous tissues in the wavelength range from 400 to $2000 \mathrm{~nm}$. Journal of Physics D: Applied Physics. 2005; 38: 2543-2555.

6. Jacques S. Optical properties of biological tissues: a review. Physics in Medicine and Biology. 2013; 58: 5007-5008. Ref.: https://goo.gl/DfwFGP

7. Jagdeo JR, Adams LE, Brody NI, Siegel DM. Transcranial Red and Near Infrared Light Transmission in a Cadaveric Model. PLoS One. 2012; 7. Ref.: https://goo.gl/qC1BTq

8. Tortamano A, Lenzi DC, Haddad AC, Bottino MC, Dominquez GC. Low-level laser therapy for pain caused by placement of the first orthodontic archwire: A randomized clinical trial. Am J Orthod Dentofacial Orthop. 2009; 136: 662-667. Ref.: https://goo.gl/5VDZY3

9. Angeletti P, Pereira MD, Gomes HC, Hino CT, Ferreira LM. Effect of low-level laser therapy (GaAlAs) on bone regeneration in midpalatal anterior suture after surgically assisted rapid maxillary expansion. Oral Surg Oral Med Oral Pathol Oral Radiol Endod. 2010; 109: 38-46. Ref.: https://goo.gl/Hm7qqB

10. Abreu ME, Viegas VN, Pagnoncelli RM, de Lima EM, Farret AM, et al. Infrared laser therapy after surgically assisted rapid palatal expansion to diminish pain and accelerate bone healing. World $\mathrm{J}$ Orthod. 2010; 11: 273-277. Ref.: https://goo.gl/iyt9aG

11. Amarillas-Escobar ED, Toranzo-Fernández JM, Martínez-Rider R, Noyola-Frías MA, Hidalgo-Hurtado $\mathrm{JA}$, et al. Use of therapeutic laser after surgical removal of impacted lower third molars. J Oral Maxillofac Surg. 2010; 68: 319-324. Ref: https://goo.gl/FD8qWa 
12. Kan B, Altay MA, Taşar F, Akova M. Low-level laser therapy supported teeth extractions of two patients receiving IV zolendronate. Lasers Med Sci. 2011; 26: 569-575. Ref.: https://goo.gl/wGMQ9H

13. García-Morales JM, Tortamano-Neto P, Todescan FF, de Andrade JC Jr, Marotti J, et al. Stability of dental implants after irradiation with an 830-nm low-level laser: a double-blind randomized clinical study. Lasers Med Sci. 2012; 27: 703-711. Ref.: https://goo.gl/mLA3cS

14. Sayed N, Murugavel C, Gnanam A. Management of Temporomandibular Disorders with Low Level Laser Therapy. J Maxillofac Oral Surg. 2014; 13: 444-450. Ref.: https://goo.gl/bq1E56

15. Prazeres LD, Muniz YV, Barros KM, Gerbi ME, Laureano Filho JR. Effect of infrared laser in the prevention and treatment of paresthesia in orthognathic surgery. J Craniofac Surg. 2013; 24: 708711. Ref.: https://goo.gl/FpuAcp 